\title{
NOTES
}

\section{FIRST RECORD OF THE PALLAS'S GRASSHOPPER WARBLER IN ALASKA}

\author{
AARON J. LANG, 40208 Alpenglow Circle, Homer, Alaska 99603; \\ aaron@wildernessbirding.com \\ STEVEN C. HEINL, 2603 Fourth Avenue, Ketchikan, Alaska 99901; \\ stevencheinl@gmail.com
}

The Pallas's Grasshopper Warbler (Helopsaltes certhiola) is common over much of its central and eastern Palearctic breeding range, which extends from the middle Irtysh River, in western Siberia, east to the Sea of Okhotsk and south to eastern Kazakhstan, northern China, and the northern coast of the Sea of Japan in the Primorskiy region of Russia (Kennerley and Pearson 2010). It winters from Sri Lanka and eastern India east through much of southeast Asia, including Sumatra and Borneo. This species is also recorded nearly annually as a fall vagrant to northwestern Europe (ibid.), and it is an irregular visitor to Japan, where at least six fall records extend from September to November (OSJ 2012). Here we report the first record of the Pallas's Grasshopper Warbler in Alaska.

On 9 September 2019 at Gambell, St. Lawrence Island, Alaska, our birding group flushed a small, buff-colored passerine with a long, rounded tail in the "near boneyard." The several boneyards at Gambell are midden sites that support dense thickets of wormwood (Artemisia sp.), which, in the fall, provide the only tall vegetative cover for migrant landbirds at Northwest Cape (Lehman 2019). Coincidentally, this bird flushed from the spot where on the previous day we had photographed a Middendorff's Grasshopper Warbler (H. ochotensis). We flushed the Pallas's several times - in each instance it flushed only when nearly under foot, then flew low over the vegetation before dropping back into cover. Upon landing, the bird moved quickly through the vegetation, requiring coordinated effort to be relocated. Given its behavior, size, and coloration we assumed we had relocated the Middendorff's from the previous day; however, Lang obtained a photograph of the bird in flight that clearly showed it had a rufous rump and strongly streaked back and lower rump, characteristics that did not fit Middendorff's.

For the next several hours our group, which now included most of the birders present at Gambell (about 16 people), worked together to obtain more views and photographs. We eventually identified the bird as a Pallas's Grasshopper Warbler, on the basis of its unmarked, yellowish-buff underparts, black-streaked crown and back, rufous or warm brown lower rump with black streaks, and brown tail with whitish tips and subtle, but broad, blackish subterminal band. In addition, the bird's face was marked by a thin dark malar streak, prominent yellow-buff supercilium, and thin brown eyeline, and the tertials were marked with small but prominent white spots on the tips of the inner webs of the feathers. Some of these features were apparent in the field, even when the bird was seen briefly in flight (Figures 1 and 2), but we were unable to obtain prolonged views of the bird on the ground. On 10 September, R. Brad Benter obtained a series of photos at close range that allowed us to eliminate similar species (Figure 3). The yellowish face and underparts identified the bird as in its year of hatching. Although three to five subspecies of Pallas's Grasshopper Warbler are recognized by various authorities, the plumage of hatching-year birds is variable and away from breeding areas such immatures cannot be identified to subspecies (Kennerley and Pearson 2010, P. Kennerley in litt., C. Goodie in litt.). The bird at Gambell was last observed on 12 September. 




Figure 1. Pallas's Grasshopper Warbler at Gambell 9 September 2019. The bird's white-tipped tail is broad and rounded and marked by a subtle blackish subterminal band. Note the overall buff-brown coloration of the upperparts, which contrast with the rufous or warm brown lower rump and uppertail coverts. The back and uppertail coverts are coarsely streaked with black, contrasting with the unmarked rump. The bird's wing coverts are blackish with contrasting narrow buff edges.

Photo by Aaron J. Lang

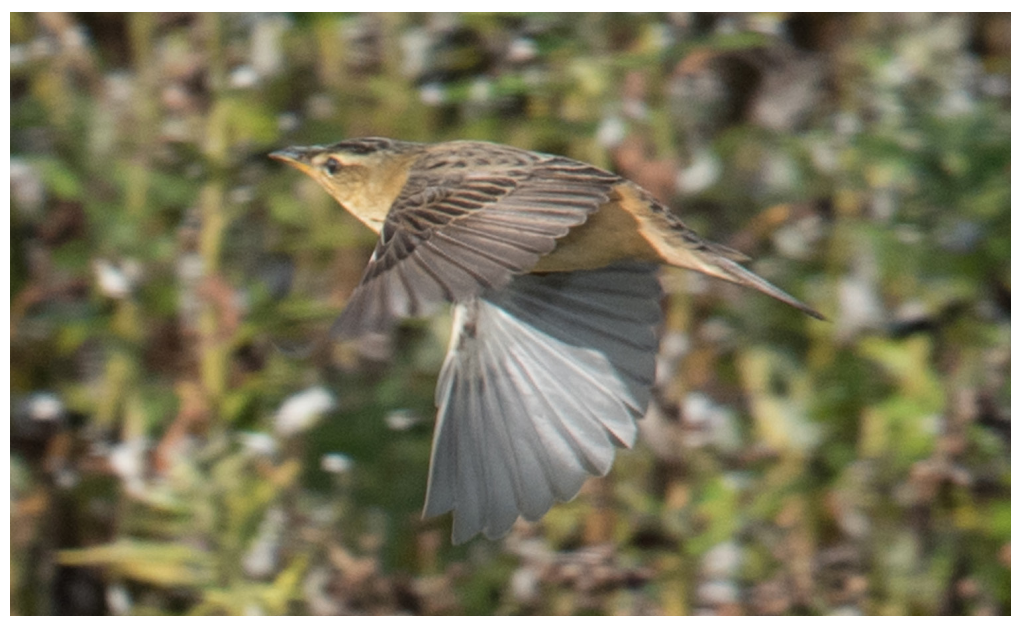

FIGURE 2. Pallas's Grasshopper Warbler at Gambell 9 September 2019. The extensive yellowish color on the underparts and face indicate a hatching-year bird. Note the prominent yellowish supercilium and lack of streaking on the undertail coverts.

Photo by Aaron J. Lang 


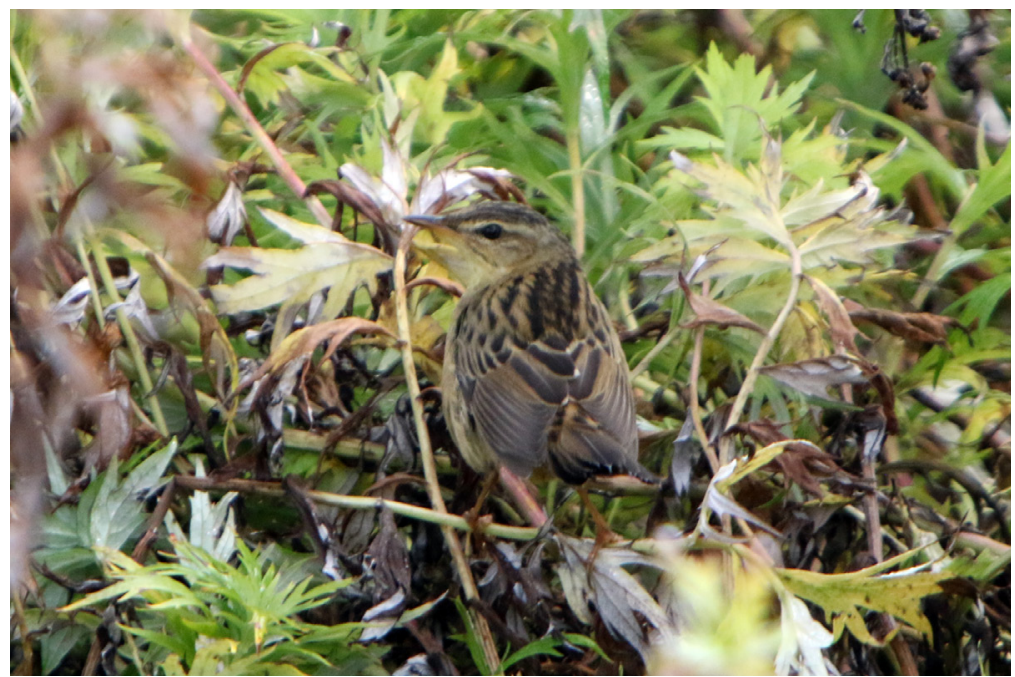

Figure 3. Pallas's Grasshopper Warbler at Gambell 10 September 2019. This photo nicely illustrates the small but prominent white spots on the inner webs of the tips of the tertials-an important field mark and the origin (along with the white-tipped tail) of the nickname "PG Tips" coined for this species by British birders. Note also the head and face pattern, including the streaked crown, prominent pale yellowish supercilium, brown eyeline, and fine dark malar line. The edges of the crown feathers are dull grayish and contrast with the warmer buff-brown back.

Photo by R. Brad Benter

The Gambell bird's streaked brownish plumage and skulking behavior immediately suggested that it was one of several migratory Palearctic warblers in the genera Locustella, Helopsaltes, or Acrocephalus, many of which can be difficult to identify. We leaned heavily on the authoritative work Reed and Bush Warblers (Kennerly and Pearson 2010) for information on identification of species in this group.

The Grasshopper (Locustella naevia) and Lanceolated (L. lanceolata) warblers are both somewhat similar in size and structure to Pallas's Grasshopper Warbler, and both are similarly well streaked on the upperparts. Locustella naevia ranges from Europe east to western China and western Mongolia, but it has been recorded as close to Alaska as the Kuril Islands (ibid.). The Lanceolated Warbler ranges from western Russia east to the Sea of Okhotsk and western Kamchatka; it is a casual visitant to the western Aleutian Islands (Gibson and Withrow 2015), where it has nested once (Andersen et al. 2008), and it has been reported twice in fall at Gambell (Lehman 2019). We eliminated those two species by their lack of rufous tones on the lower rump and uppertail coverts, plainer face patterns (shorter, less contrasting supercilium), plainer rectrices (lacking blackish subterminal band and white tips), and, in particular, their streaked undertail coverts and lack of white tips on the inner webs of the tertials. Unlike Helopsaltes certhiola and L. lanceolata, L. naevia has back feathers with buff fringes; thus the black centers of its back feathers do not extend to the tips of those feathers. Lanceolated Warblers are also crisply streaked on the chest and flanks, whereas those areas are unmarked in Pallas's Grasshopper Warbler.

The Sedge Warbler (Acrocephalus schoenobaenus) is similar in size to Pallas's Grasshopper Warbler and shares its prominent supercilium, streaked back, and 
warm brown rump (Kennerley and Pearson 2010). It ranges from Europe east through western Siberia to the Yenisey River and has been recorded twice in fall at Gambell (Rosenberg and Lehman 2008, Lehman 2019). The Sedge Warbler differs from the Pallas's Grasshopper Warbler in having a more boldly patterned crown (with bold, black lateral crown stripes), more diffuse back streaking, unstreaked rump and uppertail coverts, and a shorter tail that lacks the blackish subterminal band and white tips of Pallas's. One additional species of Helopsaltes, the Japanese Swamp Warbler (H. pryeri), and two additional species of Acrocephalus, the Aquatic (A. paludicola) and Streaked Reed (A. sorghophilus) warblers, have streaked backs but are otherwise quite different from Pallas's Grasshopper Warbler (Kennerley and Pearson 2010). We eliminated other species of Locustella, Helopsaltes, and Acrocephalus by their lack of streaks on the back, rump, and uppertail coverts.

The closely related Middendorff's Grasshopper Warbler breeds in northern Hokkaido, Sakhalin, and the Kuril Islands, and along the coasts of the Sea of Okhotsk and Kamchatka (ibid.). It is a casual visitant to the western Aleutian and Bering Sea islands (Gibson and Withrow 2015). Although Middendorff's is similar in size and shape to Pallas's, and it shares that species' white-tipped tail feathers, its plumage is much plainer and lacks the rufous lower rump and uppertail coverts and coarse streaking of Pallas's Grasshopper Warbler. Some Middendorff's, particularly those breeding in the northern Kuril Islands, northern Sea of Okhotsk, and Kamchatka, have more conspicuous darker centers to the back feathers and, in some cases, illdefined crown streaks; some also exhibit a tertial pattern with white spots at the tips of the inner webs similar to the pattern of Pallas's (Kennerley and Pearson 2010). In all respects, however, they are still much less distinctly marked than Pallas's (ibid.).

The main identification problem presented by Middendorff's is the potential for hybrids with Pallas's. The two species hybridize where their ranges overlap along the lower Amur River and in northern Sakhalin, at the northeastern edge of the range of Pallas's. The plumage of up to $70 \%$ of the breeding birds in those areas is reported to vary from almost pure Pallas's to almost pure Middendorff's, and they form a self-sustaining intergrade population (Kalyakin et al. 1993-see Kennerley and Pearson 2010:255, 264). In addition, the distribution of Pallas's and Middendorff's along the Sea of Okhotsk is uncertain, and some individuals in this range cannot be safely assigned to species. Indeed, of the three extant specimens on which A. T. von Middendorff (1853) based his original description of Sylvia (Locustella) ochotensis, all juveniles, two are somewhat intermediate toward certhiola (Loskot 2002). The taxonomic treatment of Pallas's and Middendorff's grasshopper warblers has evolved over the years from their original descriptions as separate species to treatment, along with Styan's Grasshopper Warbler (H. pleskei), as conspecific (Vaurie 1959, Williamson 1968), to the separation of Middendorff's and Pallas's, with Styan's being retained as a subspecies of Middendorff's (Dement'ev and Gladkov 1954), to the current arrangement of the three being maintained, as originally described, as separate species. We follow the recent taxonomic proposal to remove $H$. certhiola and H. ochotensis from the genus Locustella to Helopsaltes (Alström et al. 2018, Chesser et al. 2020, Praveen et al. 2020).

Despite the taxonomic ambiguity, identification of H. ochotensis and H. certhiola is straightforward, and any difficulty in distinguishing them most likely reflects a boldly marked Middendorff's versus a poorly marked Pallas's, or a hybrid (Kennerley and Pearson 2010). The boldly marked and richly colored plumage of the Gambell bird, however, was typical of Pallas's Grasshopper Warbler "in every respect” (P. Kennerley in litt.), and its plumage markings were not subdued or diffuse as expected of a hybrid. The occurrence at Gambell was accepted as the first Alaska record of the Pallas's Grasshopper Warbler by the Alaska Checklist Committee (see University of Alaska Museum Department of Ornithology https://www.universityofalaskamuseumbirds. org/bird-collection/). 


\section{NOTES}

We thank Peter Kennerley and Chris Goodie for their insightful comments on the identification of the Gambell Pallas's Grasshopper Warbler and R. Brad Benter and James D. Levison for the use of their photos, which were instrumental in establishing the identification. Daniel D. Gibson, Philip Unitt, Gary H. Rosenberg, and Paul E. Lehman provided excellent comments that improved the manuscript. We are also indebted to Philip Unitt, whose reading of Middendorff's 1853 description of ochotensis (written in German) helped clarify our statement on the taxonomic history of that species. Finally, we recognize that so many interesting North American bird records would never have been discovered without the permission of the Native Village of Gambell, Alaska. We thank the residents of Gambell for welcoming us and providing the opportunity to bird in and around their village for so many years.

\section{LITERATURE CITED}

Alström, P., Cibois, A., Irestedt, M., Zuccon, D., Gelang, M., Fjeldsa, J., Andersen, M. J., Moyle, R. G., Pasquet, E., and Olsson, U. 2018. Comprehensive molecular phylogeny of the grassbirds and allies (Locustellidae) reveals extensive non-monophyly of traditional genera, and a proposal for a new classification. Molecular Phylogenetics and Evolution 127:367-375; doi.org/10.1016/j. ympev.2018.03.029.

Andersen, E. M., Schlawe, C., and Lorenz, S. 2008. First record of the Lanceolated Warbler breeding in North America. W. Birds 39:2-7.

Chesser, T. R., Billerman, S. M., Burns, K. J., Cicero, C., Dunn, J. L., Kratter, A. W., Lovette, I. J., Mason, N. A., Rasmussen, P. C., Remsen, J. V. Jr., Stotz, D. F., and Winker, K. 2020. Sixty-first supplement to the American Ornithological Society's Check-list of North American Birds. Auk 137:1-24; doi.org/10.1093/ auk/ukaa030.

Dement'ev, G. P., and Gladkov, N. A. (eds.). 1954 (translated 1968). Birds of the Soviet Union, vol. 6. Israel Program for Scientific Translations, Jerusalem.

Gibson, D. D., and Withrow, J. J. 2015. Inventory of the species and subspecies of Alaska birds, second edition. W. Birds 46:94-185.

Kalyakin, M. V., Babenko, V. G., and Nechaev, V. A. 1993. [On the systematic relationship between Pallas's Grasshopper Warbler (Locustella certhiola) and Middendorff's Grasshopper Warbler (L. ochotensis)]. Sbor. Trud. Muz. MGU [Arch. Zool. Mus. Moscow State Univ.] 30:164-182 (in Russian).

Kennerley, P., and Pearson, D. 2010. Reed and Bush Warblers. Christopher Helm, London.

Lehman, P. E. 2019. The Birds of Gambell and St. Lawrence Island, Alaska. Studies of Western Birds 4. W. Field Ornithol., Camarillo, CA.

Loskot, V. M. 2002. On the type specimens of Locustella ochotensis (Middendorff, 1853 ) in the collection of the Zoological Institute, St. Petersburg (Aves: Sylviidae). Zoosyst. Rossica 11:239-242.

Ornithological Society of Japan (OSJ). 2012. Check-list of Japanese Birds, 7th rev. ed. Ornithol. Soc. Japan, Sanda, Japan.

Praveen, J., Jayapal, R., and Pittie, A. 2020. Taxonomic updates to the checklists of birds of India, and the South Asian region-2020. Indian Birds 16:12-19.

Rosenberg, G. H., and Lehman, P. E. 2008. First North American record of Sedge Warbler (Acrocephalus schoenobaenus) at Gambell, Alaska. N. Am. Birds 62:178-181.

Vaurie, C. 1959. The Birds of the Palearctic Fauna. Passeriformes. H. F. and G. Witherby, London.

Williamson, K. 1968. Identification for Ringers 1. The genera Cettia, Locustella, Acrocephalus, and Hippolais, 3rd ed. Br. Trust Ornithol., Tring, England. 